\title{
RECENT DEVELOPMENT AND REMAINING \\ CHALLENGES IN DETERMINING UNIQUE BRIDGE SCOUR PERFORMANCE INDICATORS
}

\author{
KENNETH GAVIN ${ }^{1 *}$, LUKE J. PRENDERGAST ${ }^{2}$, \\ IRINA STIPANOVIČ ${ }^{3,4}$, SANDRA ŠKARIČ-PALIČ ${ }^{4}$ \\ ${ }^{1}$ Faculty of Civil Engineering and Geosciences, Delft University of Technology, \\ Delft, The Netherlands \\ ${ }^{2}$ Dept of Civil Engineering, Faculty of Engineering, \\ University of Nottingham, Nottingham, United Kingdom \\ ${ }^{3}$ Faculty of Engineering Technology, University of Twente, \\ Enschede, The Netherlands \\ ${ }^{4}$ Infra Plan Consulting Ltd., Zagreb, Croatia
} Received 24 November 2017, accepted 23 August 2018

\begin{abstract}
There have been significant developments in the area of vibrationbased bridge scour monitoring in recent years. Traditional scour monitoring using either visual assessment or diving inspections are now recognised to be very unreliable and highly subjective. There has been a concerted effort to move towards reliable systems capable of either direct measurement of scour or indirect measurement, based on monitoring the response of the structure to damage. The developments have unearthed new challenges and problems. This paper describes some recent developments in the field. In addition, remaining challenges that act as a barrier to the successful wide-scale deployment of the methodologies are discussed. In particular, it addresses issues related to how to measure key performance indicators (such as the vibration response of the structure) and the potential of these approaches in real-world applications.
\end{abstract}

Keywords: bridges, monitoring, scour, sensors, uncertainty, vibration.

\footnotetext{
* Corresponding author. E-mail: k.g.gavin@tudelft.nl 


\section{Introduction}

Scour is the term given to describe the excavation and removal of material from around foundation systems of structures located in harsh hydraulic conditions. There are three main terms used to classify scour, namely general scour, contraction scour and local scour. General scour includes the natural processes of aggradation and degradation of streambeds that occur as a result of changing hydraulic parameters governing channel form such as changes in flow rate or sediment supply (Forde, McCann, Clark, Broughton, Fenning, \& Brown, 1999). General scour results in the natural evolution of the waterway and is associated with the progression of scour erosion and deposition in the absence of obstacles to the flow (Federico, Silvagni, \& Volpi, 2003). Contraction scour occurs due to sudden changes in channel geometry introducing a constriction to flow areas such as at the location of a hydraulic structure such as a bridge pier or abutments. The decrease in flow area leads to an increase in flow velocity and an associated increase in bed shear stresses. When the shear stresses imposed by the flow on the bed increase above the threshold shear stress of the bed material, the sediments mobilise enabling scour to occur (Briaud, Ting, Chen, Gudavalli, Perugu, \& Wei, 1999). The term "local scour" is given to describe erosion that occurs around hydraulic structures such as bridge piers and abutments. When the flow meets an obstacle such as a bridge pier, downward flow is induced at the upstream end leading to localised erosion around the structure (Hamill, 2014). The amalgamation of the three forms of scour described may lead to significant losses in soil from around foundation elements, that prove detrimental to the stability and safety of structures in operation.

Scour erosion of bridge foundation soil is the number one cause of bridge failure in bridges located over waterways (Forde, McCann, Clark, Broughton, Fenning, \& Brown, 1999; Melville \& Coleman, 2000; Shirole \& Holt, 1991). One study found that 53 percent of 500 bridge failures occurring between 1989 and 2000 in the United States occurred as a result of flooding and scour problems (Wardhana \& Hadipriono, 2003). This issue presents a significant cost burden on bridge owners and managers worldwide between inspections, scour protection installation and repairing damage caused by the occurrence of scour (Prendergast \& Gavin, 2014). In the United States, the average cost for flood damage repair of highways is estimated at $\$ 50$ (EUR 42) million per year (Lagasse, Zevenbergen, Spitz, \& Arneson, 2012). Scour failures typically occur quite suddenly and generally, without warning, potentially leading to loss of life. Figure 1 shows the Malahide Viaduct, in North Dublin, Ireland, that failed suddenly after a train had passed over it (Maddison, 


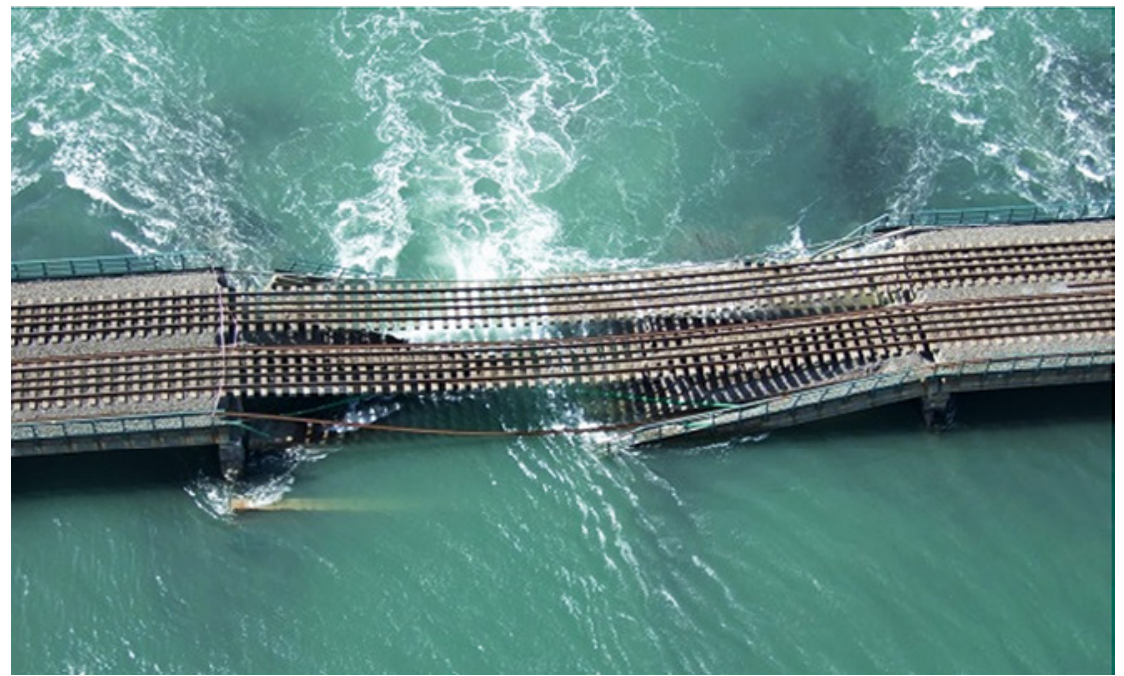

Sandra Skarič-Palič

Recent

Development and Remaining Challenges in Determining Unique Bridge Scour Performance Indicators

Figure 1. Malahide Bridge Collapse (21 $1^{\text {st }}$ of August 2009)

2012). Fortunately there were no casualties in this event; however, this section of the TEN-T railway between linebetween Dublin and Belfast, was closed for several months as a result of the collapse.

There are two primary methods of combatting the effects of scour, i.e., the use of hydraulic and structural countermeasures. Both of these methods are outlined briefly below in the paper. In tandem with the provision of scour countermeasures, it is useful to monitor the presence and severity of scouring so that effective scour mitigation regimes can be employed as part of a bridge management scheme. The current article is concerned with the discussion of ongoing challenges in this area; therefore, more attention is focussed on describing the current state-ofthe-art in the next section:

- Hydraulic countermeasures. These primarily involve maintaining larger bridge openings at the bridge design stage by reducing the size of piers or by streamlining structural elements to avoid rapid flow expansion or contraction (May, Ackers, \& Kirby, 2002);

- Structural countermeasures. At the design stage, this involves ensuring that spread footings are located below the maximum design scour depth (May, Ackers, \& Kirby, 2002). Heidarpour, Afzalimehr, \& Izadinia, (2010) highlight that the addition of riprap, rock armour or collars around bridge piers also helps to mitigate the effects of scour. Note, this countermeasure is only as accurate as existing design calculations of scour depths, which are subject to some uncertainty. 


\section{Bridge scour monitoring using a Structural Health Monitoring (SHM) techniques}

\subsection{Direct monitoring}

The accurate assessment and monitoring of existing structures to progressive scour has come to the fore of research in recent years (De Falco \& Mele, 2002; Forde, McCann, Clark, Broughton, Fenning, \& Brown, 1999). Methodologies developed can broadly be categorised as follows:

- methods, which directly measure the scour depth using instrumentation, and

- indirect methods, which infer scour severity by tracking changes in bridge modal properties, e.g., natural frequency. This has thus been identified as a key performance indicator for the scour assessment in the work of WG2 in TU1406.

A range of sensors and methods for direct scour monitoring have been developed (Prendergast \& Gavin, 2014). Simple systems such as Float-Out Devices and Tethered Buried Switches (Briaud, Hurlebaus, Chang, Yao, Sharma, Yu, ... \& Price, 2011; Hunt, 2009) float out of the soil when scour reaches their installed depth, triggering a signal. These are the simplest type of mechanical device. However, they must be reset when they float out, being maintenance intensive. Time-Domain Reflectometry (TDR) systems use changes in dielectric permittivity to monitor the location of the soil-water interface relative to a fixed probe (Fisher, Chowdhury, Khan, \& Atamturktur, 2013; Yu \& Yu, 2009). Similarly, Ground Penetrating Radar (GPR) can be used to detecting the scour holes using high-frequency electromagnetic waves, which are partially reflected as they pass through different media (Anderson, Ismael, \& Thitimakorn, 2007; Forde, McCann, Clark, Broughton, Fenning, \& Brown, 1999). These types of systems are prone to interference by external factors such as scour the whole shape, which can induce false reflections. Soundwave devices such as Sonic Fathometers (Fisher, Chowdhury, Khan, \& Atamturktur, 2013; Nassif, Ertekin, \& Davis, 2002; Prendergast \& Gavin, 2014), Reflection Seismic Profilers (Anderson, Ismael, \& Thitimakorn, 2007; Prendergast \& Gavin, 2014) and Echo Sounders (Anderson, Ismael, \& Thitimakorn, 2007) emit sonic pulses to locate the soil-water interface, and hence the scour depth, using a similar approach to the radar methods. A variety of methods relies on the installation of rods into the soil near a foundation. Magnetic Sliding Collars (MSC) (Hunt, 2009; Prendergast \& Gavin, 2014) involve monitoring the movement of a gravity-controlled sensor which sits on the streambed surrounding a rod. The sensor falls with increasing scour depth relative to the rod and closes magnetic switches along the 

that detect bed movements as sediments are scoured to their level. Zarafshan, Iranmanesh, \& Ansari (2012) developed a system, which uses changes in the vibration frequency of a driven rod to detect scour, as measured using a Fibre-Bragg Grating (FBG) sensor.

\subsection{Indirect monitoring}

Indirect monitoring methods broadly refer to the use of the response of the structure to scour to detect the presence of scour. Most of these methods involve measuring the dynamic response of a bridge or bridge element using an accelerometer or otherwise, and observing how modal properties change when the foundation stiffness is compromised by scour. A variety of authors have investigated various aspects of the potential applicability of these approaches, in (Briaud et al. , 2011; Chen, et al., 2014; Elsaid \& Seracino, 2014; Foti \& Sabia, 2010; Klinga \& Alipour, 2015; Prendergast, et al 2013, 2016 and 2017).

\section{Effective sensor placement for adequate modal analysis and detection}

One of the more pressing and less investigated problems with vibration-based scour monitoring is where to place sensors to ensure the desired modal characteristics of the structure under investigation are detected. A recent study by Prendergast et al. (2017) postulated that various sub-structural bridge elements (piers, abutment, and piles) act locally when affected by scour. This implies that a mode of vibration

Span 1

Span 2

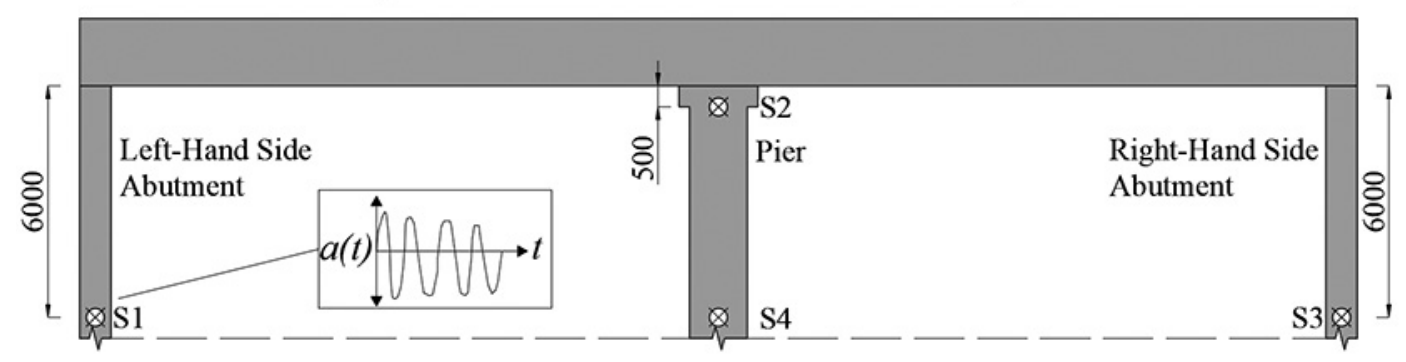

Figure 2. Sensor locations to locate the scour holes on the two-span integral bridge (Prendergast, Gavin, \& Hester, 2017) 
local to the pier, is only affected by scour at the pier (and other elements are unaffected). Using this information it is possible to design a sensor scheme that ensures the desired effects will be captured. For real systems, there are two main ways to conduct this:

- a full modal study of the structure of interest whereby the structure is mapped for its dynamic behaviour;

- the development of a numerical reference model of the test system, and the extraction of the modal effects from a mathematical representation of the real system.

For example, Figure 2 shows the sensor placement scheme to allow scour be captured for a two-span integral bridge, as was derived from a numerical reference model of the structure.

\section{Incorporation of geotechnical uncertainty}

One common omission from existing works is the fact that soil is a heterogeneous material. As a result, the frequency response will be affected by the natural variability in the stiffness of the soil deposit and ignoring this effect can lead to significant errors. The operational soil stiffness relevant to a study of the vibration response of a bridge is the small strain stiffness, $\mathrm{G}_{0}$. In practice, this quantity can be inferred from the soil strength profile (Gavin, Adekunte, \& O'Kelly, 2009). In sand

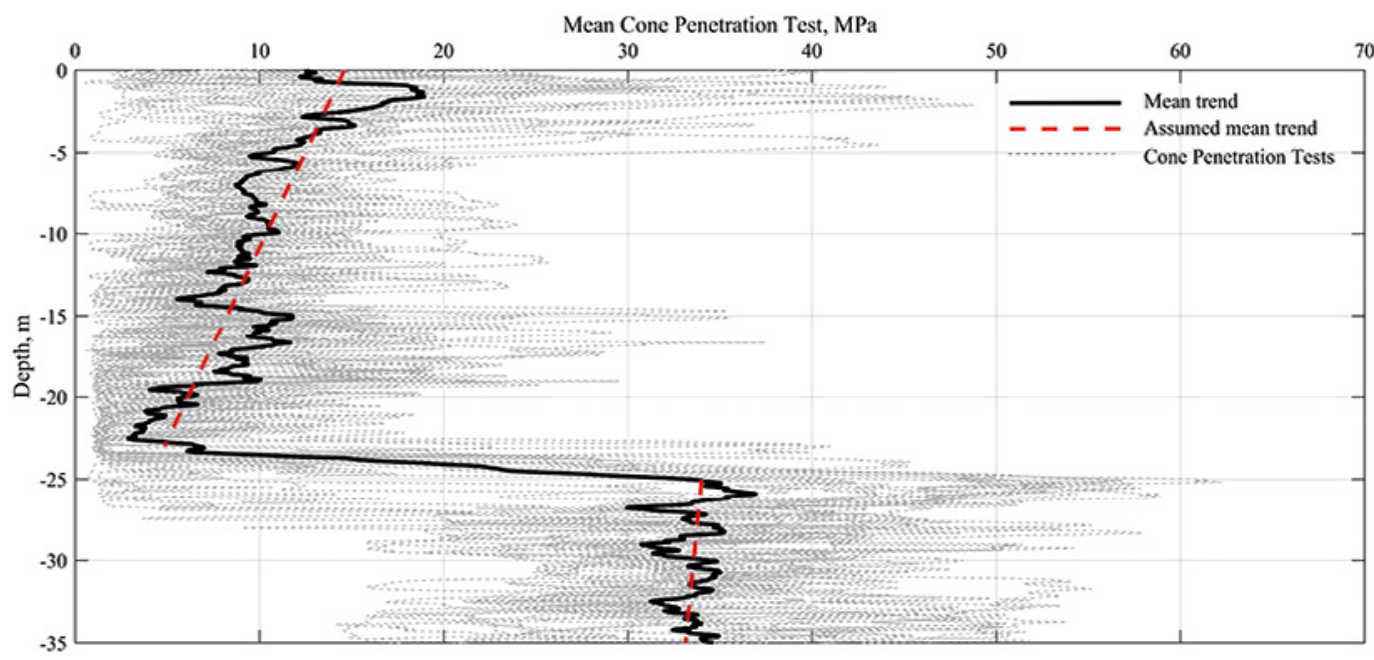

Figure 3. Example of Cone Penetration Test data and inherent variability across a site 


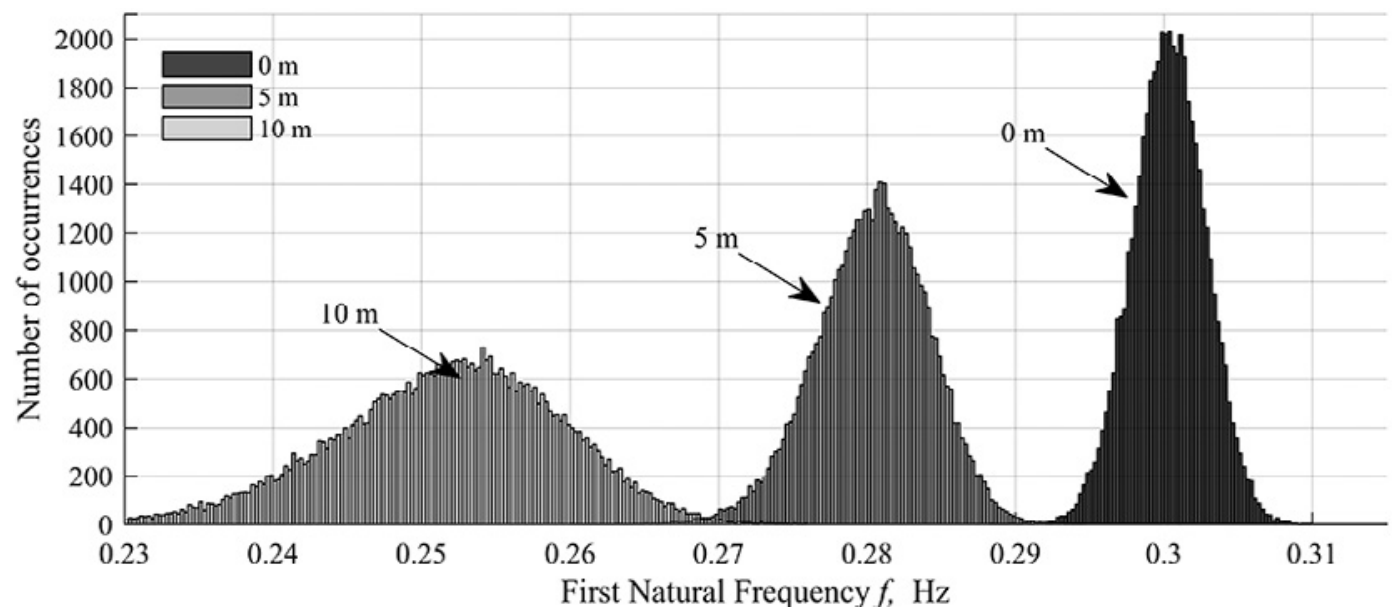

Figure 4. Distribution of Natural Frequency values when soil uncertainty is incorporated

deposits that are affected by scour the Cone Penetration Test (CPT) end resistance, $\mathrm{q}_{\mathrm{c}}$ is a reliable tool for determination of the strength profile. A typical example of the variation of $\mathrm{q}_{\mathrm{c}}$ that results from natural variability of soil is shown in Figure 3. The impact of this variability on the determination of key performance indicators is considered through a numerical analysis in the following section.

Figure 4 shows an example of the impact of variability in the expected soil stiffness on the predicted frequency of a piled structure as the scour depth increases from zero (no scour) to $10 \mathrm{~m}$ of scour. Because of the uncertainty with regard to the soil stiffness a distribution of possible output frequencies for a given scour depth is obtained, instead of deterministic (fixed) values. The apparent problem is the crossover in frequencies for each scour depth due to the shared values among distributions. The problem is excarebated as the scour depth increases. This highlights the significant uncertainty that can potentially exist in these types of analysis. Thus it indicates that more accurate ground models are required for direct scour depth inference from these vibration based approaches.

\section{Conclusions}

Remote scour monitoring is a form of structural health monitoring that offers many benefits over traditional techniques for scour detection. The principles of the approach have been demonstrated in laboratory and numerical studies and is now reaching a stage of high Technology Readiness Level. However, before the widespread 
deployment of accelerometer networks to bridges is undertaken several issues should be resolved.

Placement of sensors to capture desired motion is a topic not well investigated to date. Most studies superficially mention the placement of sensors, for example, at the top of a bridge pier. However, this may not be the most effective place to capture the requisite modal information. Recent studies have touched on this issue; however, it broadly remains an unresolved problem.

Geotechnical uncertainty has received almost no attention in previous studies, postulating the use of vibration measurements to infer scour presence and even quantifying depths. Ignoring the impact of heterogeneity may lead to incorrect predictions of scour depth. This issue will become a significant barrier to the success of both the methodology itself and the accuracy of key performance indicators if not explored in detail, as the reliance of the measured frequency on a known stiffness profile is paramount.

\section{Acknowledgements}

The authors wish to acknowledge Transport and Urban Development COST Action TU1406 "Quality Specifications for Roadway Bridges, Standardization at a European Level (BridgeSpec)" for enabling the study.

\section{REFERENCES}

Anderson, N. L., Ismael, A. M., \& Thitimakorn, T. (2007). Ground-penetrating radar: a tool for monitoring bridge scour. Environmental and Engineering Geoscience, 13(1), 1-10. https://doi.org/10.2113/gseegeosci.13.1.1

Briaud, J. L., Hurlebaus, S., Chang, K. A., Yao, C., Sharma, H., Yu, O. Y., ... \& Price, G. R. (2011). Realtime monitoring of bridge scour using remote monitoring technology. Texas Transportation Institute, Texas A\&M University System.

Briaud, J. L., Ting, F. C., Chen, H. C., Gudavalli, R., Perugu, S., \& Wei, G. (1999). SRICOS: Prediction of scour rate in cohesive soils at bridge piers. Journal of Geotechnical and Geoenvironmental Engineering, 125(4), 237-246. https://doi.org/10.1061/(ASCE)1090-0241(1999)125:4(237)

Chen, C. C., Wu, W. H., Shih, F., \& Wang, S. W. (2014). Scour evaluation for foundation of a cable-stayed bridge based on ambient vibration measurements of superstructure. NDT \& E International, 66, 16-27. https://doi.org/10.1016/j.ndteint.2014.04.005

De Falco, F., \& Mele, R. (2002). The monitoring of bridges for scour by sonar and sedimetri. NDT \& E International, 35(2), 117-123. https://doi.org/10.1016/S0963-8695(01)00031-7

Elsaid, A., \& Seracino, R. (2014). Rapid assessment of foundation scour using the dynamic features of bridge superstructure. Construction and Building Materials, 50, 42-49. https://doi.org/10.1016/j.conbuildmat.2013.08.079 
Federico, F., Silvagni, G., \& Volpi, F. (2003). Scour vulnerability of river bridge Irina Stipanovič, Sandra Skarič-Palič piers. Journal of Geotechnical and Geoenvironmental Engineering, 129(10), 890-899. https://doi.org/10.1061/(ASCE)1090-0241(2003)129:10(890)

Fisher, M., Chowdhury, M. N., Khan, A. A., \& Atamturktur, S. (2013). An evaluation of scour measurement devices. Flow Measurement and Instrumentation, 33, 55-67. https://doi.org/10.1016/j.flowmeasinst.2013.05.001

Forde, M. C., McCann, D. M., Clark, M. R., Broughton, K. J., Fenning, P. J., \& Brown, A. (1999). Radar measurement of bridge scour. Ndt \& E International, 32(8), 481-492. https://doi.org/10.1016/S0963-8695(99)00026-2

Foti, S., \& Sabia, D. (2010). Influence of foundation scour on the dynamic response of an existing bridge. Journal of bridge engineering, 16(2), 295-304. https://doi.org/10.1061/(ASCE)BE.1943-5592.0000146

Gavin, K., Adekunte, A., \& O'Kelly, B. C. (2009). A field investigation of vertical footing response on sand. https://doi.org/10.1680/geng.2009.162.5.257

Hamill, L. (2014). Bridge hydraulics. CRC Press.

Heidarpour, M., Afzalimehr, H., \& Izadinia, E. (2010). Reduction of local scour around bridge pier groups using collars. International Journal of Sediment Research, 25(4), 411-422. https://doi.org/10.1016/S1001-6279(11)60008-5

Hunt, B. E. (2009). NCHRP synthesis 396: monitoring scour critical bridges-a synthesis of highway practice. Transportation Research Board, Washington, DC.

Klinga, J. V., \& Alipour, A. (2015). Assessment of structural integrity of bridges under extreme scour conditions. Engineering Structures, 82, 55-71. https://doi.org/10.1016/j.engstruct.2014.07.021

Lagasse, P. F., Zevenbergen, L. W., Spitz, W. J., \& Arneson, L. A. (2012). Stream stability at highway structures (No. FHWA-HIF-12-004).

Maddison, B. (2012). Scour failure of bridges. Proceedings of the Institution of Civil Engineers-Forensic Engineering, 165(1), 39-52.

May, R. W. P., Ackers, J. C., \& Kirby, A. M. (2002). Manual on scour at bridges and other hydraulic structures (Vol. 551). London: Ciria.

Melville, B. W., \& Coleman, S. E. (2000). Bridge scour. Water Resources Publication.

Nassif, H., Ertekin, A. O., \& Davis, J. (2002). Evaluation of bridge scour monitoring methods. United States Department of Transportation, Federal Highway Administration, Trenton.

Prendergast, L. J., \& Gavin, K. (2014). A review of bridge scour monitoring techniques. Journal of Rock Mechanics and Geotechnical Engineering, 6(2), 138-149. https://doi.org/10.1016/j.jrmge.2014.01.007

Prendergast, L. J., Gavin, K., \& Hester, D. (2017). Isolating the location of scour-induced stiffness loss in bridges using local modal behaviour. Journal of Civil Structural Health Monitoring, 7(4), 483-503. https://doi.org/10.1007/s13349-017-0238-3

Prendergast, L. J., Hester, D., \& Gavin, K. (2016a). Determining the presence of scour around bridge foundations using vehicle-induced vibrations. Journal of Bridge Engineering, 21(10), 04016065.

https://doi.org/10.1061/(ASCE)BE.1943-5592.0000931 
Prendergast, L. J., Hester, D., \& Gavin, K. (2016b). Development of a vehicle-bridge-soil dynamic interaction model for scour damage modelling. Shock and Vibration, 2016. https://doi.org/10.1155/2016/7871089

Prendergast, L. J., Hester, D., Gavin, K., \& O’Sullivan, J. J. (2013). An investigation of the changes in the natural frequency of a pile affected by scour. Journal of Sound and Vibration, 332(25), 6685-6702. https://doi.org/10.1016/j.jsv.2013.08.020

Shirole, A. M., \& Holt, R. C. (1991). Planning for a comprehensive bridge safety assurance program. Transportation Research Record, 1290, 39-50.

Wardhana, K., \& Hadipriono, F. C. (2003). Analysis of recent bridge failures in the United States. Journal of performance of constructed facilities, 17(3), 144-150. https://doi.org/10.1061/(ASCE)0887-3828(2003)17:3(144)

Yu, X., \& Yu, X. (2009). Time domain reflectometry automatic bridge scour measurement system: principles and potentials. Structural Health Monitoring, 8(6), 463-476. https://doi.org/10.1177\%2F1475921709340965

Zarafshan, A., Iranmanesh, A., \& Ansari, F. (2011). Vibration-based method and sensor for monitoring of bridge scour. Journal of bridge engineering, 17(6), 829-838. https://doi.org/10.1061/(ASCE)BE.1943-5592.0000362 